\title{
Nutrient absorption in Tithonia Diversifolia
}

\author{
Julián Mauricio Botero Londoño, ${ }^{1,2}$, Arnulfo Gómez Carabali ${ }^{2}$, \\ Mónica Andrea Botero Londoño ${ }^{3}$
}

\footnotetext{
Edited by

Juan Carlos Salcedo-Reyes

(salcedo.juan@javeriana.edu.co)

1. Universidad Industrial de Santander, Facultad de Zootecnia, Grupo de Investigación GISEL, Campus Málaga, Málaga, Santander, Colombia, Postal Code 682011.

2. Universidad Nacional de Colombia, Facultad de Ciencias Agropecuarias, Departamento de Ciencia Animal,

Grupo de Investigación en uso y manejo de suelos y aguas con énfasis en degradación de suelos, Carrera 32 \# 12 - 00, Palmira, Valle, Colombia, Postal Code 763533.

3. Universidad Industrial de Santander, Facultad de Ingenierías Fisicomecánicas, Escuela de Ingenierías Eléctrica, Electrónica y de Telecomunicaciones, Grupo de Investigación GISEL, Carrera 27 Calle 9, Bucaramanga, Santander, Colombia, Postal Code 680002.

* ganaderiaagroforestal@gmail.com

Received: 14-02-2018

Accepted: 16-11-2018

Published on line: 05-02-2019

Citation: Botero Londoño JM, Gómez Carabali A, Botero Londoño MA.

Nutrient absorption in Tithonia diversifolia, Universitas Scientiarum, 24 (1): 33-48, 2019. doi: 10.11144/Javeriana.SC24-1.nait

Funding:

Universidad Nacional de Colombia.

Electronic supplementary material: N.A.

OPEN ACCESS
}

\begin{abstract}
Tithonia diversifolia is a robust shrub that has high ecological plasticity and adaptability, high capacity of nutrient absorption and high nutrient contents. These characteristics make Tithonia diversifolia be considered as a multi-purpose plant, such as for animal feed, soil decontamination and soil restorer. Likewise, it is a plant with high ecological plasticity and adaptability. The study of the nutrient absorption and the fertilization represent an important advance in the development of productive systems focused on maximizing forage productivity, which guarantees the soil sustainability. Based on this, a split plot design was conducted to study the effects of different levels of fertilization. The results showed an impact of the elements and levels of fertilization on the nutrient absorption capacity, finding that the elements that were incorporated in the fertilization increase the foliar contents and the nutrient absorption in the plant.
\end{abstract}

Keywords: agroforestry systems, fertilization, pastures and fodder.

\section{Introduction}

The Tithonia diversifolia is an herbaceous plant or robust shrubby that belongs to the Plantae, Tracheobionta Subrein (vascular plants), Magnoliophyta Division (plants with flower), Magnoliopsida Class (dicotyledonous), Asteridae Subclass, Asterales Order and Asteraceae family [1]. Several authors have discussed the characteristics of this plant. First, Luo et al. [2] describe the Tithonia diversifolia as an invasive plant and label it as a threat to biodiversity in the areas introduced due to its rapid and easy spread, since it grows quickly even under unfavorable conditions, multiplies easily by stakes, can withstand pruning at ground level and burning, possesses high nutrients absorption capability, 
adapts to different climate conditions and develops in a high range of soil $[3,4]$. Second, Pérez et al [1] define it as a specie with high biomass production capacity and rapid recovery after cutting. Last, Reis et al [5] found that with the application of biofertilizers to Tithonia diversifolia, soil characteristics were improved significantly, and the accumulation of nutrients in the plant was greater.

The establishment of forages increases the cation exchange capacity of the soil, maintains and increases the mesofauna, contributes to the recycling of nutrients and the mineralization of phosphorus and nitrogen, optimizes the biological cycle of carbon, improves soil structure, controls erosion, protects against soil overheating and over-cooling and is an effective mechanism for capturing and retaining atmosphere carbon $[6,7,8]$.

The basis for the efficient development of crops and soil management is built on the balance of minerals required by the plant, the contribution of the soil and the nutrients provided in the fertilization. Ensuring the supply of nutrients required by the plant based on soil deficiencies guarantees crop productivity and its sustainability [9]. The nutrient absorption capacity of the plant depends on its root system and the physical, chemical and biological conditions of the soil [10].

The knowledge of the nutritional requirements for the plant and the development of fertilization systems guarantee the maximum productivity of the crops and their sustainment over time [11]. Soil does not contain the adequate balance of nutrients for all plants, making it impossible to express their productive capacity [12]. Interpretation of soil analysis based on the contributions estimated by this and the requirements of the plant is the basis for the efficient development of crops and soil management, which warrants the productivity of the crop and the support of the soil [9]. The concentration of nutrients in the plant depends on several factors: the contribution in nutrients of the soil, nature of the plant and state of maturity of the plant. Some plants have the ability to retain high concentrations of certain elements [13], thus, knowing the ability of the plant to accumulate certain elements is essential in the development of crops for specific production purposes. In this research, the effect of different levels of fertilization on foliar contents and nutrient absorption of Tithonia diversifolia was determined.

This paper evaluates the efficiencies of the nutrient absorption, foliar contents with different level of fertilization per plant cut from Tithonia diversifolia. The project was developed in an andisol soil of the Colombian Eje Cafetero. The treatments were determined based on fertilization levels, defined from the interpretation of soil analysis and the initial nutrient absorption per plant cut 
from Tithonia diversifolia. The results show that the elements introduced in the fertilization (N-P-K) increases their concentration and their foliar content in the plants as fertilization increases as well.

\section{Materials and methods}

\section{Project location}

The project was developed in an andisol soil of the Colombian Eje Cafetero, at La Esmeralda farm in the department of Quindío, Colombia, located at $4^{\circ}$ and 38' 24" North Latitude and $75^{\circ}$ and 38' 26" West Longitude at 1680 masl, with rainfall between 2000 and $3000 \mathrm{~mm}$ per year and an average temperature of $19^{\circ} \mathrm{C}$.

\section{Soil charactetistics}

The soils presented acid $\mathrm{pH}$ values of 5.2 to 5.4 , with high contents of organic matter (8.7 - 10). The average concentration of $\mathrm{Ca}, \mathrm{Mg}, \mathrm{Al} \mathrm{I}^{1}$ and $\mathrm{K}$ was $3.82,0.39,0.20$ and $0.22 \mathrm{cmol}_{(+)} / \mathrm{kg}$, respectively. The averages in the concentrations of $\mathrm{P}, \mathrm{Cu}, \mathrm{Zn}, \mathrm{Mn}, \mathrm{Fe}$ and $\mathrm{B}$ were 6.7, 3.9, 2.9, 5.7, 143 and 0.54, respectively.

\section{Treatments determination}

The treatments were determined based on fertilization levels, defined from the interpretation of soil analysis (see section 2.2.) and the initial nutrient absorption per plant cut from Tithonia diversifolia $\left(\mathrm{N}: 4.61 \mathrm{~g}, \mathrm{P}_{2} \mathrm{O}_{5}: 0.91 \mathrm{~g}\right.$, $\mathrm{K}_{2} \mathrm{O}: 3.01 \mathrm{~g}$ ). In a crop with 50 days of recovery and at a height of $30 \mathrm{~cm}$ from the soil, 12 plants were taken at random from a previously established crop of 100 plants (without fertilization), to which the production of biomass on a dry basis and the content of nutrients at a leaf level were determined. The proposed treatments were T1: initial absorption (IA), the soil without fertilizers. Subsequently, the percentages of fertilizers and nutrients increased, for example, for T2, the initial absorption with an increase of $25 \%$ (Table 1).

\section{Experimental design}

The experimental design consisted of a randomized complete block using units of $50 \mathrm{~m}^{2}$ each with 50 plants planted per experimental unit, 4 blocks with 6 treatments each, for a total of 24 experimental units, and additionally, 4 experimental cuts were made. These cuts were done every 50 days at $30 \mathrm{~cm}$ from the soil. Fertilization was performed the day after each cut. The analyzed variables were foliar contents $(\mathrm{N}, \mathrm{P}, \mathrm{K}, \mathrm{Ca}, \mathrm{Mg}, \mathrm{Mn}, \mathrm{Fe}, \mathrm{Zn}, \mathrm{Cu}, \mathrm{B}, \mathrm{Na})$ and 
Table 1: Amount of nutrient and fertilizer applied per plant and per cut for each treatment studied. Initial Absorption (IA).

Treatments

$\mathrm{g}$ of applied nutrition

$\mathrm{g}$ of applied fertilizer

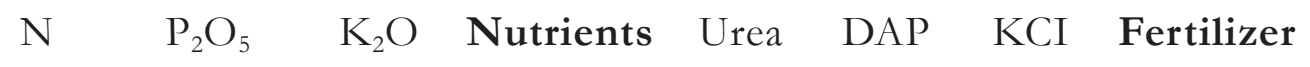

\begin{tabular}{|ccccccccc|}
\hline $\boldsymbol{T} \boldsymbol{1}-\boldsymbol{I A}$ & 0 & 0 & 0 & $\mathbf{0}$ & 0 & 0 & 0 & $\mathbf{0}$ \\
\hline $\boldsymbol{T 2}-\boldsymbol{I A}+\mathbf{2 5} \%$ & 8.85 & 3.85 & 2.31 & $\mathbf{1 5 . 0 2}$ & 15.97 & 8.37 & 3.85 & $\mathbf{2 8 . 1 9}$ \\
\hline $\boldsymbol{T 3}-\boldsymbol{I A}+\mathbf{5 0} \%$ & 11.16 & 4.99 & 3.56 & $\mathbf{1 9 . 7 1}$ & 20.02 & 10.84 & 5.94 & $\mathbf{3 6 . 8 0}$ \\
\hline $\boldsymbol{T} \boldsymbol{-}-\boldsymbol{I A}+\mathbf{7 5} \%$ & 13.46 & 6.13 & 4.82 & $\mathbf{2 4 . 4 1}$ & 24.06 & 13.32 & 8.03 & $\mathbf{4 5 . 4 1}$ \\
\hline $\boldsymbol{T 5}-\boldsymbol{I} \boldsymbol{A}+\mathbf{1 0 0} \%$ & 15.77 & 7.26 & 6.07 & $\mathbf{2 9 . 1 0}$ & 28.10 & 15.79 & 10.12 & $\mathbf{5 4 . 0 1}$ \\
\hline $\boldsymbol{T} \boldsymbol{6}-\boldsymbol{I A}+\mathbf{2 0 0} \%$ & 24.99 & 11.81 & 11.09 & $\mathbf{4 7 . 8 9}$ & 44.28 & 25.68 & 18.48 & $\mathbf{8 8 . 4 3}$ \\
\hline
\end{tabular}

nutrient absorption. The records of the examined variables were subjected to an analysis of variance according to the experimental design used in the SAS package; when there were differences $(\mathrm{P}<0.05)$, Duncan's multiple range test was used for the separation of means.

Foliar contents and nutrients absorption

For determining the nutrient absorption of the plants, 12 plants were taken per experimental unit to measure the production of biomass on a dry basis and the mineral content at the leaf level, and with the previous results the nutrient absorption was determined. The samples were analyzed based on the following laboratory tests according to the Protocolo de Laboratorio de Química de la Universidad Nacional de Colombia Palmira campus [14]: N. Kjeldahl Method; K, Ca, Mg, Mn, Fe, Zn, Cu, B: Atomic Absorption Spectroscopy; P: $\mathrm{UV}-\mathrm{V}$ is Spectroscopy.

\section{Results and Discussion}

Foliar contents and nutrients absorption

The foliar contents had statistical differences at $\mathrm{P}<0.05$ level for all the elements, except for $\mathrm{Na}$ and $\mathrm{Cu}$, finding that the elements that were introduced in the fertilization (N-P-K) show increases in their concentrations in the plants as fertilization increases; however, the elements that were not applied express a decreasing trend with fertilization (Table 2). 
Table 2: Effect of different fertilization levels of on nutrient content of Tithonia diversifolia leaves. CV: coefficient of $\mathrm{v}$ ariation. Measures in columns followed by different letters are significantly different $(\mathrm{P}<0.05)$ based on Duncan's multiple range test.

Treatments

$\left(\mathrm{g} \mathrm{kg}^{-1}\right)$

$\left(10^{-3} \mathrm{~g} \mathrm{~kg}^{-1}\right)$

\begin{tabular}{|c|c|c|c|c|c|c|c|c|c|c|c|}
\hline & $\mathbf{N}$ & $\mathrm{Ca}$ & $\mathbf{M g}$ & $\mathbf{K}$ & $\mathrm{Na}$ & $\mathbf{P}$ & $\mathrm{Cu}$ & $\mathrm{Zn}$ & Mn & $\mathrm{Fe}$ & B \\
\hline T1 & $43.7^{c}$ & $23.7^{\mathrm{a}}$ & $6.3^{\mathrm{a}}$ & $20.7^{d}$ & 0.9 & $4.9^{f}$ & 20.1 & $124.0^{\mathrm{a}}$ & $121.8^{\mathrm{a}}$ & $142.4^{\mathrm{a}}$ & $62.0^{\mathrm{a}}$ \\
\hline$T 2$ & $44.2^{c}$ & $21.7^{\mathrm{b}}$ & $6.0^{\mathrm{ab}}$ & $21.5^{\mathrm{dc}}$ & 0.9 & $5.8^{e}$ & 20.4 & $116.4^{\mathrm{b}}$ & $113.6^{\mathrm{ba}}$ & $138.2^{a}$ & $58.3^{\text {ba }}$ \\
\hline T3 & $46.1^{\mathrm{b}}$ & $19.1^{\mathrm{c}}$ & $5.8^{\mathrm{b}}$ & $22.2^{\mathrm{c}}$ & 0.9 & $6.3^{d}$ & 19.7 & $116.3^{\mathrm{b}}$ & $106.0^{\mathrm{bc}}$ & $130.4^{\mathrm{b}}$ & $57.3^{\text {ba }}$ \\
\hline$T 4$ & $46.9^{\mathrm{b}}$ & $18.0^{\mathrm{d}}$ & $5.5^{\mathrm{b}}$ & $24.0^{\mathrm{b}}$ & 0.8 & $6.9^{c}$ & 19.5 & $106.1^{\mathrm{c}}$ & $100.2^{\mathrm{dc}}$ & $124.7^{b}$ & $56.0^{\mathrm{b}}$ \\
\hline T5 & $48.9^{a}$ & $16.1^{\mathrm{e}}$ & $5.6^{\mathrm{b}}$ & $24.6^{\mathrm{ba}}$ & 0.8 & $7.5^{\mathrm{b}}$ & 20.1 & $100.0^{\mathrm{d}}$ & $93.3^{d}$ & $114.3^{c}$ & $50.8^{c}$ \\
\hline T6 & $48.4^{a}$ & $16.0^{\mathrm{e}}$ & $5.6^{\mathrm{b}}$ & $25.2^{\mathrm{a}}$ & 0.7 & $8.0^{\mathrm{a}}$ & 18.9 & $96.0^{\mathrm{d}}$ & $93.5^{\mathrm{d}}$ & $114.1^{\mathrm{c}}$ & $50.0^{c}$ \\
\hline$C V$ & 1.5 & 3.2 & 5.3 & 2.4 & 12 & 4.2 & 9.2 & 3.1 & 5.6 & 3.3 & 6.0 \\
\hline
\end{tabular}

Nitrogen $(\mathrm{N})$ did not have statistical differences at $(\mathrm{P}<0.05)$ level in $\mathrm{T} 1$ and $\mathrm{T} 2$, T3 and T4, T5 and T6 treatments, but it did between them, i.e., T1 and $\mathrm{T} 2$ present statistical differences with $\mathrm{T} 3$ and $\mathrm{T} 4$; the same situation applies to T5 and T6, indicating an increase in the plant contents as fertilization levels rose (Table 2). Consequently, this element besides stimulating the greater development of the plant, it also increases its concentrations with fertilization. The data are similar to those found by Rivera et al. [15] evaluating Tithonia diversifolia in an intensive silvopastoral system developed in soils classified as ultisols and oxisols, with very acidic $\mathrm{pH}$, high aluminum saturation, high iron and phosphorus and low organic matter contents, but superior to those mentioned by Meza et al [16] in 60 day cuts. On the other hand, Aye [17] compared the nutritional value of the leaves of Tithonia diversifolia, Moringa oleifera and Gmelina arborea, reporting lower values than those discovered in this study of Tithonia diversifolia. 
Phosphorus $(\mathrm{P})$ had statistical differences at $(\mathrm{P}<0.05)$ level between all treatments and an important effect of the levels of fertilization on its concentration in the plant (Table 2). This component is of great relevance given the cost and importance in animal feeding systems, especially in the secretion of milk, metabolism, synthesis of phospholipids and proteins. Moreover, it has a meaningful effect on food consumption, weight gain, reproductive rates and milk production. Pérez et al. [18] evaluated ten species with forage potential for feeding ruminants established in tropical soils at 80 masl in temperatures ranging between $26^{\circ} \mathrm{C}$ and $33^{\circ} \mathrm{C}$ and precipitation between 1400 and $1600 \mathrm{~mm}$ (Albizia niopoides, Gliricidia sepium, Leucaena leucocephala, Samanea saman, Acacia farnesiana, Mimosa pigra, Moringa oleifera, Brosimun alicastrum, Cordia dentata and Guazuma ulmifolia), founding lower values than those revealed in this study of Tithonia diversifolia. In contrast, Olabode et al. [3] obtained superior values in Tithonia diversifolia harvested at flowering.

Potassium $(\mathrm{K})$ had statistical differences at $(\mathrm{P}<0.05)$ level between T1, T3, $\mathrm{T} 4$ and T6 treatments, without showing differences between $\mathrm{T} 1$ and $\mathrm{T} 2$, T2 and T3, T4 and T5, T5 and T6 treatments. This evidenced a boost in their concentrations with the increase in fertilization (Table 2). Furthermore, Olabode et al. [3] reported values for Tithonia diversifolia harvested at flowering superior to those identified in Tithonia diversifolia for this study, but lower than those reported for Panicum maximum and Chromolaena odorata. On the other hand, Jama et al. [19] reported values in Tithonia diversifolia superior to those found.

Calcium $(\mathrm{Ca})$ had statistical differences at $(\mathrm{P}<0.05)$ level for all treatments, except for treatments $\mathrm{T} 5$ and $\mathrm{T} 6$, demonstrating a reduction in the concentration of nutrients in the plant as fertilization levels and biomass production increased, showing an average decrease of $9.2 \%$ in each treatment since T1 until T5, where it tends to stabilize (Table 2). These data are within the range of values observed by Rivera et al. [15] and values higher than those presented by Olabode et al. [3].

Magnesium $(\mathrm{Mg})$ had statistical differences at $(\mathrm{P}<0.05)$ level between T1 and T2, T3, T4, T5 and T6 treatments, without showing differences between the previous ones. This shows as in $\mathrm{Ca}$, a decrease in its concentrations with fertilization and biomass production (Table 2). In this study, it was found higher data than the ones reported in the literature by Olabode et al. [3] for Tithonia diversifolia harvested at flowering and similar data to those found by Figueiredo \& Grassi [20] in sunflower plants with nitrogen fertilization from different sources. 
Micronutrients presented differences $(\mathrm{P}<0.05)$ for $\mathrm{Zn}, \mathrm{Mn}, \mathrm{Fe}$ and $\mathrm{B}$ without finding differences between treatments $\mathrm{T} 5$ and $\mathrm{T} 6$ in any of these elements, showing a decrease in concentrations as fertilization levels increased (Table 2). Like the $\mathrm{Ca}$ and the $\mathrm{Mg}$, the $\mathrm{Zn}, \mathrm{Mn}, \mathrm{Fe}$ and $\mathrm{B}$, the elements that were not incorporated in the fertilization, showed a reduction when the biomass production increased, and a tendency to stabilize in T6. The effect in forages properties when the production of biomass and the fertilization increased, showed the importance of the study in techniques of soils management and fertilizers for the handling of crops. The values found in micronutrients are within the upper ranges of concentrations in the plants estimated by the Geographical Institute Agustín Codazzi [21], showing the efficiency of the plant in the absorption of nutrients.

\section{Nutrient absorption}

All the elements ( $\mathrm{N}, \mathrm{Ca}, \mathrm{Mg}, \mathrm{K}, \mathrm{P}, \mathrm{Cu}, \mathrm{Zn}, \mathrm{Mn}, \mathrm{Fe}$ and $\mathrm{B}$ ), except $\mathrm{Na}$, showed differences $(\mathrm{P}<0.05)$ of $\mathrm{T} 1$ compared to the rest. On the other hand, $\mathrm{N}$ and $\mathrm{Mn}$ showed differences between all treatments, and $\mathrm{Ca}, \mathrm{P}, \mathrm{K}$ and Fe presented differences between all treatments, except between T2 and T3 treatments, finding increases in the absorption of all elements with the rise in the levels of fertilization, given by the greater production of biomass and therefore, nutrients production (Fig. 1, Table 3).

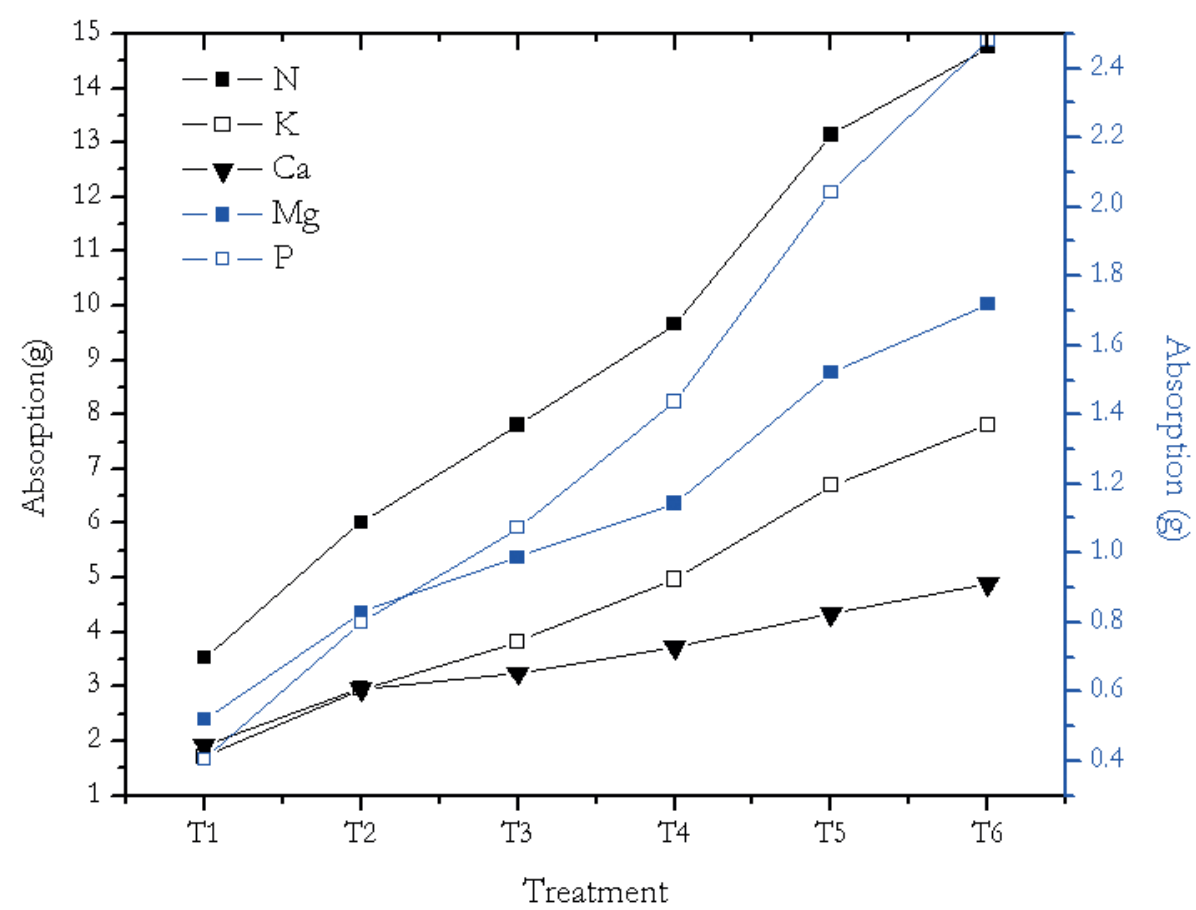

Figure 1: Effect of different fertilization level on nutrient absorption per plant cut. 
Table 3: Effect of different fertilization level on nutrient absorption per hectare of Tithonia Diversivolia plants in a year. CV: coefficient of variation. Measures in columns followed by different letters are significantly different $(\mathrm{P}<0.05)$ based on Duncan's multiple range test.

Treatments

$\left(\mathrm{kg} \mathrm{ha}^{-1}\right)$

$\begin{array}{llllllllllll}\mathbf{N} & \mathrm{Ca} & \mathrm{Mg} & \mathrm{K} & \mathrm{Na} & \mathbf{P} & \mathrm{Cu} & \mathrm{Zn} & \mathrm{Mn} & \mathrm{Fe} & \mathrm{B}\end{array}$

\begin{tabular}{|c|c|c|c|c|c|c|c|c|c|c|c|}
\hline$T 1$ & $211.7^{f}$ & $116.4^{\mathrm{e}}$ & $31.0^{\mathrm{d}}$ & $107.2^{\mathrm{e}}$ & 4.5 & $23.9^{\mathrm{e}}$ & $0.10^{\mathrm{e}}$ & $0.59^{\mathrm{d}}$ & $0.60^{\mathrm{f}}$ & $0.62^{\mathrm{e}}$ & $0.31^{\mathrm{d}}$ \\
\hline$T 2$ & $341.6^{\mathrm{e}}$ & $171.7^{\mathrm{d}}$ & $46.7^{c}$ & $177.6^{\mathrm{d}}$ & 6.7 & $45.2^{\mathrm{d}}$ & $0.16^{\mathrm{d}}$ & $0.89^{\mathrm{c}}$ & $0.92^{\mathrm{e}}$ & $0.96^{\mathrm{d}}$ & $0.48^{\mathrm{c}}$ \\
\hline T3 & $442.0^{\mathrm{d}}$ & $188.6^{\mathrm{d}}$ & $55.4^{c}$ & $227.6^{d}$ & 8.8 & $61.3^{\mathrm{d}}$ & $0.19^{c}$ & $1.13^{\mathrm{b}}$ & $1.07^{\mathrm{d}}$ & $1.12^{\mathrm{d}}$ & $0.60^{\mathrm{cb}}$ \\
\hline$T 4$ & $528.7^{\mathrm{c}}$ & $209.6^{c}$ & $61.8^{\mathrm{b}}$ & $288.0^{c}$ & 9.4 & $79.5^{\mathrm{c}}$ & $0.23^{\mathrm{b}}$ & $1.20^{\mathrm{b}}$ & $1.19^{c}$ & $1.28^{c}$ & $0.69^{\mathrm{b}}$ \\
\hline$T 5$ & $741.0^{\mathrm{b}}$ & $249.9^{\mathrm{b}}$ & $84.8^{\mathrm{a}}$ & $391.1^{\mathrm{b}}$ & 11.5 & $116.8^{b}$ & $0.31^{\mathrm{a}}$ & $1.54^{\mathrm{a}}$ & $1.49^{\mathrm{b}}$ & $1.60^{\mathrm{b}}$ & $0.82^{\mathrm{a}}$ \\
\hline$T 6$ & $829.9^{a}$ & $283.8^{a}$ & $96.9^{\mathrm{a}}$ & $461.9^{\mathrm{a}}$ & 12.0 & $141.2^{\mathrm{a}}$ & $0.33^{a}$ & $1.64^{\mathrm{a}}$ & $1.71^{\mathrm{a}}$ & $1.79^{\mathrm{a}}$ & $0.93^{a}$ \\
\hline$C V$ & 7.8 & 7.8 & 13.1 & 13.6 & 13.7 & 15.1 & 8.2 & 10.0 & 8.1 & 10.3 & 12.7 \\
\hline
\end{tabular}

The $\mathrm{N}, \mathrm{K}$ and $\mathrm{P}$ absorption since $\mathrm{T} 2 \mathrm{until} \mathrm{T} 5$ increased in average $2.37 \mathrm{~g}$ of $\mathrm{N}$, $1.25 \mathrm{~g}$ of $\mathrm{K}$ and $0.41 \mathrm{~g}$ of $\mathrm{P}$ per every $2.3 \mathrm{~g}$ of N, $1.25 \mathrm{~g}$ of $\mathrm{K}_{2} \mathrm{O}$ and $1.14 \mathrm{~g}$ of $\mathrm{P}_{2} \mathrm{O}_{5}$. On the other hand, in T6, the absorption of $\mathrm{N}, \mathrm{K}$ and $\mathrm{P}$ increased with fertilization $1.6 \mathrm{~g}, 1.1 \mathrm{~g}$ and $0.44 \mathrm{~g}$, respectively for each $9.22 \mathrm{~g}$ of $\mathrm{N}, 5.02 \mathrm{~g}$ of $\mathrm{K}_{2} \mathrm{O}$ and $4.55 \mathrm{~g}$ of $\mathrm{P}_{2} \mathrm{O}_{5}$. Moreover, in biomass production, since T2 until T5 it was observed an increase in $44.3 \mathrm{~g}$ of dry matter (DM) per every $8.6 \mathrm{~g}$ fertilizer established. By contrast, in T6, the DM increase $35.9 \mathrm{~g}$ per every $34.4 \mathrm{~g}$ fertilizer incorporated. These results showed that nutrient uptake for $\mathrm{N}, \mathrm{K}$ and $\mathrm{P}$ was better in $\mathrm{T} 5$ than T6, where a considerably decrease was found.

When the increase in absorption of $\mathrm{N}, \mathrm{P}$ and $\mathrm{K}(3.9,5.9$ and 4.3 times, respectively) was observed (T1-T6), the absorption of those elements that were not included in fertilization also increases between 2.5 and 3.3 times. This demonstrates that the application of major elements has an effect on the total absorption of elements (Table 3). 
The nutrient absorption per hectare year expressed in $\mathrm{N}, \mathrm{P}_{2} \mathrm{O}_{5}$ and $\mathrm{K}_{2} \mathrm{O}$ presented in the T1 extractions of 212.54 and $129 \mathrm{~kg} \mathrm{ha}^{-1}$ of $\mathrm{N}, \mathrm{P}_{2} \mathrm{O}_{5}$ and $\mathrm{K}_{2} \mathrm{O}$, respectively, and in the T6 extractions of 830,324 and $557 \mathrm{~kg} \mathrm{ha}^{-1}$ of $\mathrm{N}, \mathrm{P}_{2} \mathrm{O}_{5}$ and $\mathrm{K}_{2} \mathrm{O}$ accordingly, evidencing high increases with fertilization. Likewise, it is of paramount importance to highlight the low absorption per hectare year of the minor elements such as $\mathrm{Cu}, \mathrm{Zn}, \mathrm{Mn}, \mathrm{Fe}$ and $\mathrm{B}$ (Table 3). This demonstrates the sensitivity of the incorporation of these elements in the soil since the greater percentage of tropical soils has acidic characteristics, which present adequate or excessive concentrations of such elements.

Fallas et al. [22] studied the absorption curves of nutrients in papaya during the vegetative period until the beginning of the harvest, finding extractions of 354,101 and $498 \mathrm{~kg} \mathrm{ha}^{-1}$ year of $\mathrm{N}, \mathrm{P}_{2} \mathrm{O}_{5}$ and $\mathrm{K}_{2} \mathrm{O}$ respectively. Additionally, Estrada [23] reported extractions in 12 different pastures in a data collection; it was found that the only species one that presented values higher or similar to those exposed by Tithonia diversifolia was Pennisetum Purpureum. This demonstrates the ability of Tithonia diversifolia to extract and produce large amounts of biomass and nutrients. Moreover, González [24] studied the efficient use and apparent recovery of nitrogen in forage maize with different doses of fertilization of $\mathrm{N}$ in clay and sandy soils, showing the importance of the interaction between fertilization and soil to the ability of extracting nutrients in plants and of studying the efficiency on fertilization.

The results found in this work are consistent with those presented by Jama et al [19], Opala et al [25] George et al and Mustonen et al [26] who found that with the addition of $\mathrm{P}$ in fertilization, the concentration and absorption of this element was increased.

\section{Conclusions}

The relation of nutrients shows an interesting behavior in the development of the crop, finding that the elements that are introduced in the fertilization (N-P-K) display significant increases in the foliar contents. However, the elements that were not applied show a tendency to decrease with fertilization. Nevertheless, the absorption of plant nutrients presents an increase in all elements with the rise in fertilization levels, demonstrating that the plant has a high nutrient absorption capacity that translates into high biomass production and converts the plant into an important fodder material for animal production and other uses.

\section{Acknowledgements}

The authors thank Universidad Nacional de Colombia for its support in the research, el laboratorio de Química of Universidad Nacional de Colombia, 
Palmira campus for their support in the analysis of the samples and the company Ganadería Agroforestal La Esmeralda for allowing the development of the research at La Esmeralda farm, located in Circasia (Quindio, Colombia, South America).

\section{Conflict of interest}

The authors declare no conflict of interest.

\section{References}

[1] Pérez A, Montejo I, Iglesias J, López O, Martín G, García D, Hernández A. Tithonia diversifolia (Hemsl.) A. Gray, Pastos y Forrajes, 32(1): 1-15, 2009.

Retrieved from:

https://payfo.ihatuey.cu/index.php?journal=pasto\&page= article\&op $=$ view \&path $\% 5 B \% 5 \mathrm{D}=652 \&$ path $\% 5 \mathrm{~B} \% 5 \mathrm{D}=154$

[2] Luo L, Zhang P, Ou X, Geng Y. Development of EST-SSR Markers for the Invasive Plant Tithonia diversifolia (Asteraceae), Applications in Plant Sciences, 4(7): 1600011, 2016.

doi: 10.3732 /apps.1600011

[3] Olabode OS, Sola O, Akanbi WB, Adesina OG, Babajide PA. Evaluation of Tithonia diversifolia (Hemsl.) A gray for soil improvement, World Journal of Agricultural Sciences, 3(4): 503-507, 2007.

Retrieved from https://pdfs.semanticscholar.org/0d9b/e6920f9fa8c05bfdaba9786a5af1ab93ef16.pdf?_ga=2.94115741.1617898098.151952443240271175.1519524432

[4] Peters M, Franco LH, Schmidt A, Hincapie B. Especies forrajeras multipropósito: opciones para productores de Centroamérica, International Center for Tropical Agriculture (CIAT), Bundesministerium fur Wirtschaftliche Zusammenarbeit und Entwicklung (BMZ), Dutsche Gesellschaft fur technische Zusammenarbeit (GTZ) Cali Colombia 2002.

[5] Reis MM, Santos LD, Pegoraro RF, Colen F, Rocha LM, Ferreira GADP. Nutrition of Tithonia diversifolia and attributes of the soil fertilized with biofertilizer in irrigated system, Revista Brasileira de Engenharia Agricola e Ambiental, 20(11): 1008-1013, 2016.

Retrieved from https://dx.doi.org/10.1590/1807-1929/agriambi.v20n11p1008-1013 
[6] Cerrato RF, Alarcón A. La microbiología del suelo en la agricultura sostenible, Ciencia ergo-sum, 8(2): 175-183, 2001.

Retrieved from

http://www.redalyc.org/articulo.oa?id=10402108

[7] Givens DI, Owen E, Axford RFE, Omed HM. Forage evaluation in ruminant nutritions. CAB International, London, UK, 2000.

[8] Socarrás A, Izquierdo I. Evaluation of agroecological systems through biological indicators of the soil quality: edaphic mesofauna, Pastos y Forrajes, 37(1): 109-114, 2014.

Retrieved from:

https:// payfo.ihatuey.cu/index.php?journal=pasto\&page= article\&op $=$ view \&path $\% 5 B \% 5 D=1782 \&$ path $\% 5 B \% 5 D=2930$

[9] Azcón J, Talón M. Fundamentos de fisiología vegetal, MacGrawHill Interamericana, Madrid, España, Segunda edición, 2008.

[10] Sánchez M. Las endomicorrizas: Expresión Bioedáfica de importancia en el trópico, Universidad Nacional de Colombia sede Palmira, Palmira, Colombia 2007.

[11] Omaña H, Peña H. Acumulación de materia seca y balance de nutrientes en tomate (Solanum lycopersicum L.) cultivado en ambiente protegido, Bioagro, 27(2): 111-120, 2015.

Retrieved from http://www.redalyc.org/pdf/857/85741585007.pdf

[12] Mejía M, Gratzfeld J, Luzio W, Menis M, Fick K, McDowell L, Conrad J. Conceptos sobre fisiología de absorción y funciones de los minerales en la nutrición de plantas, Editorial Universidad Nacional de Colombia, Palmira, Colombia 2010.

[13] Estrada J. Pastos y Forrajes para el trópico colombiano. Manizales. Editorial Universidad de Caldas, Manizales, Colombia 2002.

[14] Laboratorio de Nutrición Animal. Protocolos de Laboratorio. Análisis de Alimentos y Forrajes. Universidad Nacional de Colombia, Palmira, Colombia 2016.

[15] Rivera JE, Cuartas CA, Naranjo JF, Tafur O, Hurtado EA, Arenas FA, Chará J, Murgueitio E. Efecto de la oferta y el consumo de Tithonia diversifolia en un sistema silvopastoril intensivo (SSPi), en la calidad y productividad de leche bovina en el piedemonte Amazónico colombiano, Livestock Research for Rural Development, 27(10): 189-200, 2015.

Retrieved from http://www.lrrd.org/lrrd27/10/ rive27189.html 
[16] Meza GA, Loor NJ, Sánchez AR, Avellaneda JH, Meza CJ, Vera DF, Cabanilla MG, Liuba GA, Meza JS, Meza FF, Ramírez MA, Moncayo OF, Cadena DL, Villamar RO, Díaz E, Rizzo LM, Rodríguez JM, López FX. Inclusión de harinas de follajes arbóreos y arbustivos tropicales (Morus alba, Erythrina poeppigiana, Tithonia diversifolia E Hibiscus rosa-sinensis) en la alimentación de cuyes (Cavia porcellus Linnaeus), Revista de la Facultad de Medicina Veterinaria y de Zootecnia, 61(3): 258-269, 2014.

doi: 10.15446/rfmvz.v61n3.46874

[17] Aye PA. Comparative nutritive value of Moringa oleifera, Tithonia diversifolia and Gmelina arborea leaf meals, American Journal of Food and Nutrition, 6(1): 23-32, 2016.

doi: $10.5251 /$ ajfn.2016.6.1.23.32

[18] Pérez N, Muhammad I, Villanueva C, Skarpe C, Guerin H. Diversidad forrajera tropical 1. Selección y uso de leñosas forrajeras en sistemas de alimentación ganadera para zonas secas de Nicaragua, Agroforestería en las Américas, 50: 37-43, 2013.

Retrieved from

http:/ /hdl.handle.net/11250/2467521

[19] Jama B, Palm CA, Buresh RJ, Niang A, Gachengo C, Nziguheba G, Amadalo B. Tithonia diversifolia as a green manure for soil fertility improvement in western Kenya: A review, Agroforestry Systems, 49: 201-221, 2000.

doi: 10.1023/A:1006339025728

[20] Figueiredo T, Grassi H. Sewage sludge levels on the development and nutrition of sunflower plants, Revista de la ciencia del suelo $y$ nutrición vegetal, 9(3): 245-255, 2009.

doi: 10.4067/S0718-27912009000300007

[21] Consideraciones generales para interpretar análisis de suelos. Instituto Geográfico Agustín Codazzi (IGAC) Colombia. Bogotá, Colombia 1998.

[22] Fallas R, Bertsch F, Barrientos M. Curvas de absorción de nutrientes en papaya (Carica papaya L.) cv. "Pococí" en las fases de crecimiento vegetativo, floración e inicio de cosecha, Agronomia Costarricense, 38(2): 43-54, 2014.

Retrieved from

https://revistas.ucr.ac.cr/index.php/agrocost/article/ view/17273/16759 
[23] Estrada J. Pastos y Forrajes para el trópico colombiano, Editorial Universidad de Caldas, Manizales, Colombia 2002.

[24] González A, Figueroa U, Preciado P, Núñez G, Ortega L, Guadalupe J, Antuna O. Efficient use and apparent recuperation of nitrogen in fodder corn at different grounds, Revista Mexicana de Ciencias Agricolas, 7(2): 301-309, 2016.

Retrieved from http://www.scielo.org.mx/scielo.php?script=sci_arttext\& pid=S2007-09342016000200301\&lng=es\&nrm $=$ iso

[25] Opala PA, Okalebo JR, Othieno CO, Kisinyo P. Effect of organic and inorganic phosphorus sources on maize yields in an acid soil in western Kenya, Nutrient Cycling in Agroecosystems, 86(3): 317-329, 2010.

doi: $10.1007 /$ s10705-009-9294-3

[26] Mustonen PSJ, Oelbermann M, Kass DCL. Response of the common bean (Phaseolus vulgaris L.) to Tithonia diversifolia (Hamsl.) Gray biomass retention or removal in a slash and mulch agroforestry system, Agroforestry Systems, 88(11): 1-10, 2014.

doi: 10.1007/s10457-013-9650-9 


\section{Absorción de Nutrientes en Tithonia diversifolia}

Resumen. Tithonia diversifolia es un arbusto robusto que tiene alta plasticidad ecológica y adaptabilidad, alta capacidad de absorción de nutrientes y alto contenido de nutrientes. Estas características hacen que Tithonia diversifolia sea considerada una planta multipropósito, tanto para alimento animal como para descontaminación y restauración del suelo. El estudio de la absorción de nutrientes y la fertilización representa un avance importante en el desarrollo de sistemas productivos enfocados en la maximización de la productividad de forraje, lo cual garantiza la sostenibilidad del suelo. Con base en esto, se llevó a cabo un diseño experimental de parcelas divididas con el fin de estudiar los efectos de diferentes niveles de fertilización. Los resultados mostraron un impacto de los elementos y los niveles de fertilización en la capacidad de absorción de nutrientes; se encontró que los elementos que fueron incorporados en la fertilización incrementan los contenidos foliares y la absorción de nutrientes en la planta.

Palabras clave: sistemas agroforestales; fertilización; pastizales; forraje. 


\section{Absorção de nutrientes em Tithonia diversifolia}

Resumo. Tithonia diversifolia é um arbusto robusto que tem alta plasticidade ecológica e adaptabilidade, alta capacidade de absorção de nutrientes e alto conteúdo de nutrientes. Estas características fazem com que Tithonia diversifolia seja considerada uma planta multipropósito, tanto para alimento animal como para descontaminação e restauração do solo. O estudo da absorção de nutrientes e da fertilização representa um avance importante no desenvolvimento de sistemas produtivos enfocados na otimizacao da produtividade de forragem, o que garante a sustentabilidade do solo. Baseado em esto, se realizou um desenho experimental de parcelas divididas com a finalidade de estudar os efeitos de diferentes níveis de fertilização. Os resultados mostraram um impacto dos elementos e dos níveis de fertilização na capacidade de absorção de nutrientes. Se encontrou que os elementos que foram incorporados na fertilização incrementam os conteúdos foliares e a absorção de nutrientes na planta.

Palavras-chave: Sistemas agroflorestais; fertilização; pastagens; forragem. 


\section{Julian Mauricio Botero Londoño}

Is an animal productor scientist, graduated from the Universidad de Santa Rosa de Cabal (Unisarc), Santa Rosa De Cabal, Colombia. MSc in Agricultural Science and PhD in Agricultural Science, both degrees awarded by Universidad Nacional de Colombia, Palmira, Colombia. Currently, Professor at the Universidad Industrial de Santander. ORCID: 0000-0002-4318-8221

\section{Arnulfo Gómez Carabali}

Is an Agronomic Engineer graduated from Universidad Nacional de Colombia, Palmira, Colombia. MSc in Range Sciences and PhD in range sciences, both degrees awarded by New Mexico State University. Currently, Professor at Universidad Nacional de Colombia, Palmira, Colombia.

\section{Mónica Andrea Botero Londoño}

Is an Electrical Engineer graduated from the Escuela Colombiana de Ingeniería "Julio Garavito", Bogotá, Colombia. MSc in Physics from Universidad Nacional de Colombia, Manizales, Colombia. PhD in Science-Physics at Universidad Nacional de Colombia, Bogotá, Colombia. Currently, Professor at the Universidad Industrial de Santander, Bucaramanga, Colombia.

ORCID: 0000-0003-1706-3182 